\title{
Does the Corporate Financial
}

\section{Architecture of Innovative Companies Differ? The Evidence From the USA}

\author{
Irina Ivashkovskaya \\ Professor, Head of School of Finance, \\ National Research University Higher School of Economics, \\ 26 Shabolovka St, Moscow, Russia \\ E-mail: iivashkovskaja@hse.ru
}

\author{
Sergei Evdokimov \\ Corporate Finance Research Center, \\ National Research University Higher School of Economics, \\ 26 Shabolovka St, Moscow, Russia \\ E-mail: sergeyevdokimov1@gmail.com
}

\begin{abstract}
Each company operates within the framework of interrelated structures: ownership, corporate governance and capital structure. The particular combination of these dimensions determines the corporate financial architecture of the company. Despite the growing body of literature on the challenges of the knowledge economy to the structural dimensions of companies, still little is known about the financial architecture of innovative firms. At the same time it is widely recognized that such companies substantially differ from traditional types of businesses in their business models and dynamics. Meanwhile, the financial architecture of a company generates the distribution of the incentives to enhance innovations affecting interests and risk-sharing among stakeholders. To address the lack of research into the interaction of corporate structures and their distinct features in innovative companies, this paper aims at identifying the robust financial architecture patterns of innovative companies. Using a sample of more than 1,300 publicly traded US-based manufacturing companies, we use an agglomerative hierarchical clustering method to identify relevant patterns and compare them to the firms which are not considered to be 'knowledge intensive'. The empirical results allow the identification of seven robust financial architecture patterns within innovative companies. Our findings show that the first major difference between the financial architecture of innovative and non-innovative firms is in the higher role of activist institutional investors in the ownership. The second notable difference is related to CEO-duality, which plays a significant role in corporate governance only in innovative firms. Moreover, innovative companies are less leveraged than non-innovative firms. In addition, mature innovative companies demonstrate better financial performance.
\end{abstract}

Keywords: innovative firms, ownership structure, governance, financial architecture, companies' performance, cluster analysis

JEL: G30, G32 


\section{Introduction}

In recent years, studies of innovative companies have been growing in importance worldwide and it is widely recognized that these firms represent original constructs. Bettencourt and co-authors define innovative firms as 'organizations where primary value-added activities consist of the accumulation, creation and dissemination of knowledge for the purpose of providing customized services and products' [1]. Many scholars study the nature of innovative activities, analyzing various types of firms [2], industries, [3] and countries [4]. Despite the observed interest towards innovative firms and their relative uniqueness, little is known about the interaction between their corporate fundamental structures.

In general, previous research has mainly focused on a stand-alone corporate structural dimension, rather than considering a combination of structures. In this paper we aim to close these gaps by examining corporate financial architecture, which is comprised of three core structures, namely: corporate governance, ownership, and capital structure [5]. Following this [6], we focus on an integrated framework derived from financial architecture when all three dimensions interact and predetermine the relevant incentives of major stakeholders in innovation activity within companies. The clear advantage of this approach is the possibility of exploring the patterns of interconnected corporate structures by grouping similar sets of characteristics together. To assess the financial architecture components altogether, we apply an agglomerative hierarchical clustering approach.

This paper contributes to the literature by revealing the robust financial architecture patterns of innovative and non-innovative companies. In this context, our findings allow us to present seven distinct patterns of financial architecture in innovative companies out of the sample of over 1,300 public US-based manufacturing companies. Four out of the seven patterns demonstrate strong differences in stakeholders' motivation and combinations of corporate structures. The remaining three clusters show limited differences that include companies with diversified ownership structures. Finally, we observed certain notable differences among samples of innovative and non-innovative firms: i) activist institutional investors being interested in the increase of the firm's value support innovation activities and thus have higher presence among innovative patterns; ii) CEO-duality plays a crucial role in the structure of financial architecture patterns among innovative firms, since the CEO's broader authority and control over board enhances innovation activity; iii) innovative firms use less debt financing having higher interest costs probably as the result of engagement in risky business operations and unstable cash flows.

The rest of the paper is organized as follows. The next section provides an overview of the literature on innovative companies and existing research on financial architecture components, when taken as stand-alone features. Following the literature review, we derive research hypoth- eses. Section 3 is devoted to the methodology and data description. The section 4 presents the empirical results of clustering and comparative analyses. The findings and the conclusions that can be drawn from this study are discussed in the section 5 .

\section{Literature review and hypotheses}

The business of every firm is based and realized within the framework of interrelated structures - ownership structure, corporate control and board of directors structures, capital structures, etc. The particular combination of these three structures forms the financial architecture of the company [5]. It affects interests, motives and strategic goals, investment risks, and its distribution both among investors and all the stakeholders. That's why it also maybe addressed as financial design of the firm which provides a framework for its dynamics. In addition to the impact of financial architecture, the intellectual capital plays a major role in success in innovative companies from the point of view of knowledge usage and also new knowledge creation. The financial architecture of the firm should generate the right distribution of incentives to provide for the efficient usage of intellectual resources. Thus, especially for innovative companies, interactions between financial architecture and components of intellectual capital have exceptional importance. Nevertheless, in most cases in the existing literature the above-mentioned structures follow stylized research models when addressing financial and strategic decisions of the examined firms, including innovative companies. The stylized approach is generally focused on stand-alone structure (ownership, governance or capital structures) as a dominant driver of performance.

The ownership structure as well as the structure of corporate governance have been on the research agenda for many years. However, only a few papers consider the interrelation between these parameters simultaneously. There are studies on the relationship between ownership structures and corporate governance mechanisms $[7,8]$. The endogenous nature of ownership structure was also addressed (e.g. external blockholders) and the relationship between ownership structure and capital structure was confirmed [9]. Over the last decade several studies have appeared on the specificity of innovation-driven companies considering their ownership [10], capital structure choices [11] as well as corporate governance mechanisms [12].

To capture these interrelations, we apply the multi-dimensional concept known as "financial architecture" [5]. It takes into account the entire financial design of the business and allows us to simultaneously include ownership, the organization's legal form, incentives, funding and allocation of risk. The empirical analysis of corporate financial architecture based on integrated research model was already introduced on the data from emerging markets [6]. Additional empirical evidence was presented in the book [13] on different samples from some developed and emerging capital markets' firms. Given this concept, not only has a better understanding of links between 
corporate structures and their impact over performance been shown, but some sustainable financial architecture patterns have also been revealed $[13,14]$. Nevertheless, the studies on interaction between these three types of structural dimensions in innovative firms are still missing.
With the growing popularity of innovation, many researchers focus on analyses of innovation-specific features. In particular, the studies on the influence of innovation activity on corporate structures are summarized in Table 1 .

Table 1. Papers studying the interrelations between corporate structures and innovation activity

\begin{tabular}{|c|c|c|}
\hline $\begin{array}{l}\text { Corporate } \\
\text { structures }\end{array}$ & Research results & Author(s) \\
\hline \multirow{2}{*}{$\begin{array}{l}\text { Capital } \\
\text { structure }\end{array}$} & $\begin{array}{l}\text { The debt financing is relatively expensive for innovative companies with low tangible } \\
\text { asset-base, because of higher default losses incurred by debt providers }\end{array}$ & {$[15]$} \\
\hline & $\begin{array}{l}\text { Risky projects taken by shareholders lead to volatile cash flows, whereas debtholders } \\
\text { anticipating such behavior makes debt raising expensive and put additional financial } \\
\text { constraints }\end{array}$ & {$[16]$} \\
\hline \multirow{3}{*}{$\begin{array}{l}\text { Ownership } \\
\text { structure }\end{array}$} & $\begin{array}{l}\text { Ownership concentration negatively affects innovation by reducing R\&D effort because } \\
\text { of conflicts between large and minority shareholders }\end{array}$ & {$[10]$} \\
\hline & $\begin{array}{l}\text { Activist institutional investors with long investment horizon (e.g. pension funds, private } \\
\text { equity funds, educational/cultural endowments) are likely to commit resources and to } \\
\text { support investments in long-term innovation activities increasing the firm value }\end{array}$ & {$[17,18]$} \\
\hline & $\begin{array}{l}\text { The incorporation of top-level executive in shareholders positively affects innovation, } \\
\text { because managers are willing to take a risk of uncertain value-enhancing innovation } \\
\text { projects in return of the profits }\end{array}$ & {$[19]$} \\
\hline \multirow{5}{*}{$\begin{array}{l}\text { Corporate } \\
\text { governance }\end{array}$} & $\begin{array}{l}\text { The presence of independent directors on the board may provide greater expertise and } \\
\text { diversity in technology affecting in innovation activity }\end{array}$ & {$[20,21]$} \\
\hline & $\begin{array}{l}\text { On the other hand, independent board enhance monitoring activity within the company } \\
\text { which may potentially lead to short-term focus of manager }\end{array}$ & {$[22]$} \\
\hline & $\begin{array}{l}\text { The presence of CFO on the board may result in strong monitoring and financial } \\
\text { conservatism that eventually decrease the number of registered patents and patent } \\
\text { citations. }\end{array}$ & {$[23]$} \\
\hline & $\begin{array}{l}\text { CFOs prefer short-term earnings targets to long-term firm value eventually leading to } \\
\text { lower innovation activity }\end{array}$ & {$[24]$} \\
\hline & $\begin{array}{l}\text { CEO-duality may result in higher innovation activity through a broader authority and } \\
\text { control over the board }\end{array}$ & {$[25]$} \\
\hline
\end{tabular}

According to the studies in table 1, the knowledge-intensity and risk of innovation activities, results in significant capital expenditures, a large share of immaterial assets, specific human capital [17], huge R\&D investments, and volatile cash flows. The nature of these features directly affects the motivation and risk sharing of shareholders [22]. Previous research does not account for the interrelations between key corporate structures, each of which is related to innovation activity. The understanding of interrelations between these non-financial characteristics is especially important for analyzing innovative companies, where innovation activity affect interests, motives and the investment risks of stakeholders in multiple dimensions.

Therefore, we focus on the identification of robust financial architecture patterns among innovative companies and have formulated the following hypothesis:
Hypothesis 1: There are several robust corporate financial architecture patterns among innovative companies

It is important to take note of a popular belief that components of financial architecture are interconnected with the company's industry [26]. To check whether the obtained patterns are not totally related to industry of companies included in one cluster, we test the following hypothesis:

Hypothesis 2: There is no industry influence on the companies' types of financial architecture among innovative companies

In addition, to have a broader understanding of innovation-driven companies we compare the financial architecture of innovative companies with other type of firms.

Hypothesis 3: The financial architecture patterns of innovative companies differ from financial architecture patterns of non-innovative companies 


\section{Methodology and data}

To identify innovative companies, a large body of papers use the Oslo Manual [27], which distinguishes several types of manufacturing companies based on the technological intensity of their business operations. According to NACE Rev 2.3 [27] manufacturing firms are divided into high (more than $4 \%$ of R\&D to sales), medium-high, medium-low and low technology companies. In fact, the use of a $\mathrm{R} \& \mathrm{D}$-to-sales indicator is more appropriate for manufacturing firms rather than service companies [28]. Within the scope of this research, we consider only manufacturing firms, building on a greater availability of data and higher relevance indicators for innovation activity for these types of firms [29]. Given that R\&D is a good proxy for innovation performance [27], we consider high-technology companies as innovative companies, and medium-high, medium-low and low-technology companies as "non-innovative firms".

We conducted the analysis on a sample of over 1,300 US-based publicly traded manufacturing companies (SIC

Table 2. Description of financial architecture's indicators
20-39). In accordance with OECD guidelines, companies are categorized as high-technology business enterprises if they meet certain classifications of economic activities: 21, 26 and 30.3 NACE rev. 2 3-digits level [27]. The financial data was collected from annual reports provided by S\&P Capital IQ database. The selection criteria for the sample are listed below:

- $\quad$ Return on assets $\geq-150 \%$

- Total assets size $\geq \$ 0.1$ million

- Ratio of long-term debt to capital $\leq 200 \%$

The total sample of firms matching the criteria is conclusively made of 486 innovative and 849 non-innovative companies. The descriptive statistics of the innovative and non-innovative companies is presented in the annex (Tables A1 and A2).

To identify corporate financial architecture patterns, we apply clustering method with specific set of variables. The variables describing financial architecture are presented below in the Table 2 .
Variable
Description
Comments

\section{Capital structure}

LTDebt_cap

Ratio of long-term debt to total capital
Given the existing data limitations, we focus on book values. Long-term debt forms the financial design, while shortterm debt is primarily used to run current business operations

\section{Ownership structure}

Institutions

by the institutional investor

(excl. venture capital, private

equity groups)

Insiders

- by insiders
Out of the available literature conducted so far the dominant approach of tracking ownership concentration includes the percentage of shares held by the largest shareholder [30] and the five largest shareholders [31]
VCPE

- by venture capital, private equity investors

Active - by insiders

institutions

- by activist institutional investors

Passive

- by activist institutional investors

institutions
- by passive institutional investors
All ownership data is collected from S\&P Capital IQ database.

Only 100 largest shareholders are considered given data limitations 


\section{Corporate governance mechanism}

\begin{tabular}{|c|c|c|}
\hline Duality & $\begin{array}{l}\text { A dummy variable which equals } 1 \text { if } \\
\text { the firm's chief executive officer is the } \\
\text { chairman position on the board, } 0 \\
\text { otherwise }\end{array}$ & \multirow{4}{*}{$\begin{array}{l}\text { The information is collected based on the } \\
\text { titles of board members provided by S\&P } \\
\text { Capital IQ }\end{array}$} \\
\hline Founder & $\begin{array}{l}\text { The percentage of board places held } \\
\text { by founders }\end{array}$ & \\
\hline $\mathrm{CFO}$ & $\begin{array}{l}\text { The percentage of places held by the } \\
\text { chief financial officer }\end{array}$ & \\
\hline Scientists & $\begin{array}{l}\text { The percentage of places held } \\
\text { by board members with the title } \\
\text { including words "scientific, strategy, } \\
\text { technology, clinical, pharmaceutical, } \\
\text { medical" }\end{array}$ & \\
\hline
\end{tabular}

We also examine the sample by studying the behavior of general variables, summarized in the table 3 below.

Table 3. Description of general variables

\begin{tabular}{|c|c|}
\hline Variable & Description \\
\hline Age & Difference between 2015 and company's foundation year \\
\hline Revenue & Annual revenue in $\$$ million \\
\hline Assets & Total assets in $\$$ million \\
\hline $\mathrm{ROA}$ & EBIT to average total assets \\
\hline Tobinq & Market to book value \\
\hline Debt_cap & Total debt to total capital \\
\hline Ia_ta & Intangible to total assets \\
\hline rd_sales & Annual R\&D expenses to total assets \\
\hline Board_size & Total number of board members \\
\hline Gr_sales & Compound annual growth rate of revenue (CAGR) over 2013-2015 years \\
\hline
\end{tabular}

There are several different types of clustering methods that are commonly used by researchers: partitioning around medoids (PAM) and hierarchical clustering (HC) methods. The agglomerative hierarchical clustering method considers each observation as an individual cluster, until the most similar clusters are merged leaving one big group. In comparison to PAM, the agglomerative
HC method does not need the pre-specified number of clusters to be created. The agglomerative hierarchical clustering method together with the Manhattan distance (less sensitive than the Euclidian variant) is applied to study the financial architecture features of innovative companies, while the PAM method is used to check the robustness of the clustering results. 


\section{Results}

\section{Optimal number of clusters}

To evaluate the clustering tendency, the Hopkins statistics is calculated. The analysis (formula 1) shows that samples of both innovative and non-innovative companies are highly clusterable:

$H_{I C}=0.1567, H_{N I C}=0.0938$

The visual assessment of the cluster tendency is performed by computing the dissimilarity matrix between the variables in the data set using the Manhattan distance measurement. The dissimilarity matrices generally confirm that samples have a clusterable structure (Figures A1 and A2). The technical analysis shows that the optimal number of clusters is seven for both innovative and non-innovative types of companies (Figure A3). The lower number of clusters result in missing meaningful clusters, whereas the consideration of additional clus- ters substantially decreases the technical accuracy of the clustering analysis. To verify the hierarchical cluster tree, the correlation between the cophenetic distance and the original distance is calculated. The value of correlation (formula 2) higher than 0.5 indicates that clustering accurately reflects the initial data:

$\operatorname{Corr}_{I C}=0.5229, \operatorname{Corr}_{\text {NIC }}=0.6074$

The metric confirms the presence of seven robust corporate financial architecture patterns among innovative companies, and therefore we do not reject $\mathrm{H} 1$.

\section{Financial architecture patterns of innovative companies}

Based on the hierarchical clustering method, we got seven distinct clusters of financial architecture for the innovative companies. The descriptive statistics of these clusters of innovative companies is presented in the table 4 below (mean statistics presented in Table A3).

Table 4. The descriptive statistics of innovative companies' clusters (median by HCA-method)

\begin{tabular}{|c|c|c|c|c|c|c|c|}
\hline Variables - median & 1 & 2 & 3 & 4 & 5 & 6 & 7 \\
\hline Age & 31.5 & 15.0 & 24.5 & 21.0 & 28.0 & 28.0 & 31.5 \\
\hline Revenue, \$m & 8.5 & 19.6 & 24.4 & 49.6 & 27.5 & 290.3 & $1,129.5$ \\
\hline Assets, \$m & 8.8 & 96.5 & 57.2 & 113.6 & 55.2 & 500.8 & $1,918.6$ \\
\hline ROA, \% & $(7.4)$ & $(20.3)$ & $(10.6)$ & $(4.0)$ & $(0.9)$ & 2.5 & 5.0 \\
\hline Gr_sales, \% & 0.0 & 11.3 & 0.0 & 3.1 & 1.8 & 6.2 & 6.7 \\
\hline ia_ta, \% & 0.7 & 1.6 & 2.6 & 5.0 & 2.3 & 13.4 & 23.9 \\
\hline Tobinq & 1.1 & 2.3 & 1.9 & 1.1 & 1.0 & 1.6 & 1.5 \\
\hline rd_sales, \% & 0.0 & 9.3 & 7.3 & 10.6 & 4.1 & 9.3 & 6.4 \\
\hline LTDebt_cap, \% & 0.0 & 1.6 & 0.0 & 0.0 & 0.0 & 14.9 & 24.8 \\
\hline Debt_cap, \% & 5.9 & 12.9 & 0.8 & 0.6 & 5.7 & 20.5 & 29.0 \\
\hline Top1, \% & 25.3 & 19.1 & 7.0 & 10.9 & 23.9 & 11.2 & 10.8 \\
\hline Top5, \% & 49.5 & 53.6 & 19.3 & 27.3 & 51.9 & 34.5 & 37.7 \\
\hline Institutions, \% & 4.3 & 23.6 & 16.8 & 19.4 & 12.4 & 56.7 & 63.9 \\
\hline Insiders, \% & 32.0 & 2.1 & 3.8 & 6.7 & 36.4 & 1.0 & 0.7 \\
\hline VCPE, \% & 0.0 & 32.1 & 0.0 & 0.0 & 0.0 & 0.0 & 0.0 \\
\hline Active_institutions, \% & 0.5 & 19.2 & 10.3 & 15.7 & 10.6 & 40.4 & 44.7 \\
\hline Passive_institutions, \% & 0.0 & 2.4 & 4.9 & 4.5 & 1.4 & 15.8 & 17.9 \\
\hline Duality & 1.0 & 0.0 & 0.0 & 1.0 & 0.0 & 0.0 & 1.0 \\
\hline Founder, \% & 0.0 & 0.0 & 0.0 & 0.0 & 0.0 & 0.0 & 0.0 \\
\hline $\mathrm{CFO}, \%$ & 22.5 & 0.0 & 0.0 & 0.0 & 0.0 & 0.0 & 0.0 \\
\hline Scientists, \% & 0.0 & 13.4 & 0.0 & 0.0 & 0.0 & 0.0 & 0.0 \\
\hline Board_size & 5.0 & 10.0 & 9.0 & 7.0 & 8.0 & 9.0 & 9.0 \\
\hline \# of companies & 18 & 50 & 72 & 52 & 66 & 174 & 54 \\
\hline
\end{tabular}




\section{Cluster 1 - "Owner-manager-controlled"}

The cluster primarily consists of companies with high proportion of blockholders in the ownership, where the largest shareholder owns over $25 \%$ of stake in the company. Strong influential power of insiders on the board's decisions is one of the pivot characteristics of this cluster given the level of ownership concentration and high insider ownership ratio (median of $32.0 \%$ ). Solid CEO-duality (on average of $100 \%$ ), strong presence of CFO (median of $22.5 \%$ ) and founders (average of 6.7\%) on the small board reinforces the board dependency. Taking into account the above-mentioned characteristics and active presence of owners as CEOs, we could characterize this pattern as owner-manager-controlled firms [32]. Given strict control over decision-making process, these type of companies are not popular among institutional investors, venture capital and private equity groups, and their presence in the ownership remains very limited. These ownership structure and corporate governance mechanisms are a common practice among small-sized firms (with a median revenue below $\$ 10 \mathrm{mln}$ ) owned by families or entrepreneurs. Solid CFO presence on the board could increase monitoring, leading to additional financial constraints [23] that eventually decrease innovation activity and result in low compounded annual growth rate (median revenue CAGR of $0 \%$ ). The observed negative financial performance (median ROA of -7.4\%) indicates inefficiency of this cluster comparing to others.

\section{Cluster 2 - "Start-ups"}

Cluster 2 demonstrates the clear representation of private equity funds (PE) and venture capital (VC) groups among shareholders (median of 32.1\%). High institutional ownership ratio (median of $23.6 \%$ ), relatively concentrated ownership structure (top-5 owners hold 53.6\%) as well as the active presence of scientists (median of $13.4 \%$ ) and founders (average of 5.7\%) on the large board of directors correspond to start-up companies. Relatively small debt (median leverage ratio of $12.9 \%$ ) attracted with the assistance of VC and PE highlight the level of risk incurred by these companies. In support of our hypothesis about start-ups, young age (median of 15.0) and high revenue CAGR (median of $11.3 \%$ ) are typical characteristics for companies that are at an the early-stage of their lifecycle. Although start-ups have the lowest financial performance among peers (median ROA of $-20.3 \%$ ), the market to book value is the highest among innovative companies (median of 2.3) indicating firms' high potential for further growth. This cluster mainly covers firms operating in pharmaceutical and biotechnology industries.

\section{Cluster 3 - "Diversified ownership"}

Cluster 3 has the most diversified ownership structure among innovative companies with the top- 5 shareholders having below $20 \%$ of shares. Insiders and institutional investors represent about $20 \%$ of shareholders in total, while public corporations and other shareholders control approximately $80 \%$ of shares. Such a dispersed owner- ship structure is common observed in Anglo-American countries [33]. A median Tobin's Q of 1.9 and a negative median ROA of $-10.6 \%$ with almost zero median revenue CAGR of companies indicate relatively high capital appreciation by the market.

\section{Cluster 4 - "Dependent board"}

The core features include the ultimate executive power of the CEO (who is also a Chairman of the small board), and a substantial presence of founders (average of $8.0 \%$ ) on the board. Both the presence of founders and a small insider ownership level (median of 6.7\%) indicate that companies previously were undergoing ownership changes, whereas founder's experience and knowledge are crucial to run business. The cluster primarily contains high R\&D investing firms with the largest median R\&D - to - sales ratio of $10.6 \%$ among innovative firms. Even though cluster 4 has a larger annual revenue and assets size, as well as a higher revenue CAGR and return on assets than cluster 3, its Tobin's Q is lower (with a median of 1.1). Such a market-based performance is the result of unstable cash flows and high risks associated with innovation activity.

\section{Cluster 5 - "Dominance of insider ownership"}

This type of company has the highest insider ownership (median of 36.4\%) among innovative companies. With this level of insider ownership and concentration ratio (top- 5 controls over $50 \%$ of equity stake), we observe the expected CEO-duality among $40 \%$ of cases. This pattern demonstrates the lowest market performance with median Tobin's Q of 1.0. Therefore, we could say that this type of financial architecture does not provide good access to the external financing.

\section{Cluster 6 - "Classic mature companies"}

This pattern is represented by classic mature companies that are primarily owned by activist institutional investors (median of 40.4\%) and are debt financed (median longterm debt-to-capital ratio of $14.9 \%)$. The strong board independency is the remarkable specific feature of the pattern. Despite having high R\&D investing activity, cluster 6 has stable financial performance with median ROA of $2.5 \%$ and revenue CAGR of $6.2 \%$. Given the business scale (median revenue of $\$ 290 \mathrm{mln}$ ), companies' age (median of 28 years) and CEO's independency, we could characterize this pattern as being indicative of "classic mature companies".

\section{Cluster 7 - "Blue chip firms with solid CEO-duality"}

This cluster differs from the previous one not only by an unusual corporate governance configuration with solid CEO-duality (100\%), but also by capital structure, which has substantially higher leverage ratio (median debt-to-capital ratio of $24.8 \%$ ). Such a phenomenon might be the result of a CEO's strong power, which enhances creditors' trust in the companies and consequently decreases risk of default, and thus lowering the cost of debt. These firms have the largest revenue size (median of $\$ 1,130 \mathrm{mln}$ ) and the largest intangible assets 
base (median of 23.9\%) demonstrating the best financial performance (median ROA of 5.0\% and revenue CAGR of $6.7 \%$ ) among peers. Given the presence of CEO-duality, large business scale, sound financial performance and the sample of well-known publicly listed companies included in this cluster (e.g. Cisco System and NVIDIA Corporation), we could name the pattern as "blue chip" firms with solid CEO-duality.

In addition to the observed distinct features of the patterns, we have also identified the differences in financial and market-based performance of the companies belonging to different clusters (table 4). Almost all innovative companies have negative accounting-based performance measures (ROA) except mature companies (clusters 6 and 7), which display stable financial performance and positive returns. As to other clusters, we observe that clusters 1, 4 and 5 perform relatively better than clusters 2 and 3, while having substantially lower market-to-book ratios. As could be anticipated, start-ups have the highest Tobin's Q given their high potential for further growth.

\section{Differences in financial architectures of innovative and non-innovative companies}

The descriptive statistics for the non-innovative companies, according to the HCA-method, is given in table 5 (mean statistics presented in Table A4).

Table 5. The descriptive statistics of non-innovative companies' clusters (median by HCA-method)

\begin{tabular}{|c|c|c|c|c|c|c|c|}
\hline Variables - median & 1 & 2 & 3 & 4 & 5 & 6 & 7 \\
\hline Age & 26.5 & 22.5 & 29.0 & 29.0 & 40.0 & 53.0 & 76.0 \\
\hline Revenue & 6.4 & 122.9 & 39.8 & 314.5 & 136.8 & $1,213.7$ & $2,514.8$ \\
\hline Assets & 5.0 & 143.6 & 49.6 & 368.9 & 140.6 & $1,380.6$ & $2,470.4$ \\
\hline ROA, \% & $(6.5)$ & 1.2 & $(3.4)$ & 3.4 & 3.1 & 5.2 & 6.8 \\
\hline Gr_sales, \% & 5.8 & 10.6 & 3.7 & 7.6 & 2.0 & 1.6 & 2.1 \\
\hline ia_ta, \% & 0.2 & 11.4 & 2.8 & 5.6 & 5.2 & 20.9 & 20.0 \\
\hline tobinq & 1.3 & 1.1 & 1.2 & 1.9 & 0.9 & 1.1 & 1.2 \\
\hline rd_sales, \% & 0.2 & 0.2 & 4.2 & 0.0 & 0.0 & 0.0 & 0.0 \\
\hline LTDebt_cap, \% & 8.5 & 14.1 & 0.0 & 7.1 & 14.1 & 32.4 & 33.3 \\
\hline Debt_cap, \% & 19.6 & 29.2 & 7.3 & 10.6 & 26.6 & 35.4 & 37.3 \\
\hline Top1, \% & 22.1 & 31.2 & 8.5 & 14.7 & 38.2 & 9.6 & 8.9 \\
\hline Top5, \% & 42.3 & 58.3 & 24.8 & 37.8 & 61.5 & 32.2 & 31.2 \\
\hline Institutions, \% & 0.0 & 18.2 & 15.4 & 38.2 & 16.0 & 57.3 & 57.8 \\
\hline Insiders, \% & 35.9 & 1.8 & 5.3 & 18.9 & 24.6 & 1.2 & 0.9 \\
\hline VCPE, \% & 0.0 & 39.0 & 0.0 & 0.0 & 0.0 & 0.0 & 0.0 \\
\hline Active_institutions, \% & 0.0 & 13.0 & 9.8 & 14.8 & 5.8 & 40.4 & 41.0 \\
\hline Passive_institutions, $\%$ & 0.0 & 4.1 & 5.5 & 14.7 & 4.5 & 17.3 & 18.4 \\
\hline Duality & 1.0 & 0.0 & 0.0 & 1.0 & 0.0 & 0.0 & 1.0 \\
\hline Founder, \% & 0.0 & 0.0 & 0.0 & 16.7 & 0.0 & 0.0 & 0.0 \\
\hline CFO, \% & 22.5 & 0.0 & 0.0 & 0.0 & 0.0 & 0.0 & 0.0 \\
\hline Scientists, \% & 0.0 & 0.0 & 0.0 & 0.0 & 0.0 & 0.0 & 0.0 \\
\hline Board_size & 4.0 & 9.0 & 7.0 & 7.0 & 7.0 & 9.0 & 10.0 \\
\hline \# of companies & 30 & 20 & 110 & 71 & 127 & 289 & 202 \\
\hline
\end{tabular}

Given the data from table 5, we summarize the features of financial architecture patterns within this subsample below. 


\section{Cluster 1 - "Insiders-controlled"}

In comparison to the "owner-manager-controlled" pattern, this cluster has a lower presence of CEO-duality (average of 50\%) and founders (average of 1.7\%) on the board. Even though each board member has broader authority over corporate decisions as a result of the slightly lower size of the board (4 members), absence of solid CEO-duality might result in conflict situations between stakeholders. At the same time, we observe the active usage of debt financing by managers. In comparison to the innovative financial architecture pattern of "owner-manager-controlled" firms, this cluster has a larger insider ownership level (median of 35.9\%), but a lower CEO-duality and founder presence, therefore the pattern's most appropriate descriptor is "insiders-controlled".

\section{Cluster 2 - "Cash generating portfolio companies"}

Taking into consideration the ownership concentration ratio (top-1 accounts for 31.2\%) and the fact that almost $40 \%$ of shares belong to VC and PE groups, we could state that this pattern consists of $\mathrm{VC}$ and PE portfolio companies. However, in the case of innovative firms we talked about start-ups, here we observe "cash generating portfolio companies" on another stage of the life-cycle. A strong CEO-duality (median of 50\%) and a large stake of top-1 shareholder are typical features of VC and PE firms willing to control the decision making process within a company. In addition, the absence of founders and low presence of scientists (average of 8.6\%) among board members indicate that these companies have undergone a board optimization process.

In support of our hypothesis, a large business scale (median revenue of $\$ 122.9 \mathrm{mln}$ versus $\$ 19.6 \mathrm{mln}$ ), intangible assets base (median of 11.4\%) and low R\&D-to-revenue ratio (median of $0.2 \%$ ) demonstrate a successfully created business model with accumulated capital. In addition, strong financial performance (median ROA of $1.2 \%$ ) and impressive revenue CAGR (median of 10.6\%) indicate stable cash inflows.

\section{Cluster 3 - "Diversified ownership"}

Highly diversified ownership is the core feature of this pattern. The primary differentiating features include a lower presence of activist institutional investors, which might be the result of a relatively conservative board structure with CEO-duality and small board size. Given that activist shareholders prefer to actively engage in operating businesses, such a board structure and a slightly higher level of insider ownership (median of 5.3\%) may negatively affect their interest.

\section{Cluster 4 - "Founders' firms"}

First, ownership concentration is relatively higher for non-innovative firms (both top- 1 and top- 5 shareholders control bigger stakes). Second, we observe the increasing role of institutional investors (median of 38.2\%) and insiders (median of 18.9\%) among owners. Third, the active presence of founders (average of 17.7\%) on the board with lower CEO-duality (average of 50\%) still demonstrate strong board dependency. It seems that such an active presence of founders on the board (who have a stake in the company), attracts the attention of institutional investors, which are willing to invest in the company governed by loyal founders. Moreover, creditors' trust in founders controlled firms may decrease costs of debt eventually leading to usage of long-term debt financing (median of 7.1\%). The appropriate title for this pattern is therefore suggested as "Founders' firms".

\section{Cluster 5 - "Concentrated ownership"}

In the case of non-innovative firms this pattern could be characterized as concentrated ownership, given the equity stake controlled by blockholders (top- 5 shareholders own $61.5 \%$ of company). The insider ownership ratio is lower in comparison to innovative firms (median of $25 \%$ ), while institutional ownership is higher (median of 16.0\%). The remaining ownership quotient is primarily accounted for by publicly traded corporations and other shareholders ( $50 \%$ of equity).

\section{Cluster 6 - "Classic mature companies"}

The major difference between innovative and non-innovative firms is observed in the capital structure. Non-innovative companies are more leveraged (median long-term debt to capital ratio of $32.4 \%$ versus $14.9 \%$ ) and have almost no founders and scientists on their boards.

\section{Cluster 7 - "Blue chip firms with solid CEO-duality"}

Innovative companies are less leveraged than non-innovative firms (a median long-term debt to capital ratio of $24.8 \%$ ) given higher interest costs occurring as the result of risky business operations and strong R\&D investing activity.

To check Hypothesis 3 on substantial differences in financial architecture between both types of firms, we match the financial architecture patterns of innovative and non-innovative firms and compare them between each other (Table 6).

Comparing the financial architecture patterns of innovative and non-innovative companies, we observe strong dissimilarities among clusters 1, 2, 4 and 5. Nevertheless, the partial correspondence of the financial architecture patterns is observed in clusters 3,6 and 7. As outlined previously, cluster 3 has a type of ownership structure which is popular in Anglo-American countries, a postulation which is borne out in our analysis. In addition, we observe clusters 6 and 7 that are similar for both innovative and non-innovative companies. Such a phenomenon might be explained by the fact that financial architectures of mature well-established companies are driven by factors that are indifferent to the level of innovation activity within the companies. The above-mentioned results of the comparative analysis allow us to reasonably conclude that financial architecture patterns of innovative and non-innovative companies are different. Thus, we do not reject hypothesis 3. 
Moreover, the following differences between innovative and non-innovative firms were observed:

- Capital structure: innovative companies use less debt financing (both long-term and total debt) to run business operations. Such behavior might be the explained by the financial restrictions implied by the debt providers or high costs of debt financing for engagement in risky business operations [16] and high losses in case of default [15].

- Corporate governance: financial architecture patterns of innovative companies are significantly linked to the CEO-duality parameter (clusters 1, 4 and 7), whereas non-innovative companies' patterns are usually indifferent to CEO-duality (from 30\% to 50\% almost in each cluster). Therefore, we could state that CEO's power plays a crucial role in the structure of financial architecture patterns among innovative firms. Indeed, CEO-duality leads to broader authority and control over the board, which substantially results in higher innovation activity [25].

- Ownership structure: innovative companies tend to have a higher presence of active institutional investors among stakeholders, whereas noninnovative companies have a higher share of passive institutional investors. Activist institutional investors commit resources to support innovation activities increasing firm value [17].

- Financial performance: Non-innovative firms show a higher return on assets in each cluster, whereas Tobin's Q is much lower in nearly every cluster (excluding clusters 1 and 4). At the same revenue, CAGR is substantially higher for innovative companies only among mature well- established firms (clusters 6 and 7), which highlights the important role of continuous R\&D investments in large businesses.

Table 6. Comparison between financial architecture patterns of innovation and non-innovative companies

\begin{tabular}{|c|c|c|c|c|c|c|}
\hline \multirow{2}{*}{ № } & \multicolumn{3}{|c|}{ Innovative companies } & \multicolumn{3}{|c|}{ Non-innovative companies } \\
\hline & Num & Name & Features & Num & Name & Features \\
\hline 1 & 18 & $\begin{array}{l}\text { Owner- } \\
\text { manager- } \\
\text { controlled }\end{array}$ & $\begin{array}{l}\text { - } 100 \% \text { CEO-duality } \\
\text { - } \text { CEOs are owners } \\
\text { - } \text { concentrated and } \\
\text { insider ownership } \\
\text { - } \\
\text { active presence } \\
\text { of CFOs on small } \\
\text { board }\end{array}$ & 30 & $\begin{array}{l}\text { Insiders- } \\
\text { controlled }\end{array}$ & $\begin{array}{l}\text {-the highest insider } \\
\text { ownership level } \\
\text {-50\% CEO-duality } \\
\text {-absence of institutional } \\
\text { investors among owners } \\
\text {-active presence of CFOs } \\
\text { on small board }\end{array}$ \\
\hline 2 & 50 & Start-ups & 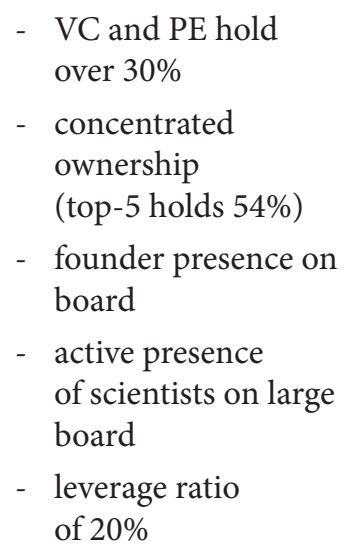 & 20 & $\begin{array}{l}\text { Cash } \\
\text { generating } \\
\text { portfolio } \\
\text { companies }\end{array}$ & $\begin{array}{l}\text {-VC and PE hold over } \\
40 \% \\
\text {-top- } 1 \text { controls over } 30 \% \\
\text {-50\% CEO-duality } \\
\text {-no founders on board } \\
\text {-leverage ratio of } 30 \%\end{array}$ \\
\hline
\end{tabular}

$3 \quad 72$

$\begin{array}{lll}\text { Diversified } & - & \text { top-5 shareholders } \\ \text { ownership } & \text { own } 20 \% \\ & - & \text { insiders and } \\ & \text { institutional } \\ & \text { investors own } \\ & \text { approximately 20\% }\end{array}$

110

Diversified ownership

\author{
-top-5 shareholders own \\ $25 \%$ \\ -insiders and institutional \\ investors own \\ approximately $20 \%$
}




\begin{tabular}{|c|c|c|c|c|c|c|}
\hline \multirow{2}{*}{ № } & \multicolumn{3}{|c|}{ Innovative companies } & \multicolumn{3}{|c|}{ Non-innovative companies } \\
\hline & Num & Name & Features & Num & Name & Features \\
\hline 4 & 52 & $\begin{array}{l}\text { Dependent } \\
\text { board }\end{array}$ & $\begin{array}{ll}\text { - } & \text { 100\% CEO-duality } \\
\text { - } & \text { dispersed ownership } \\
\text { - } & \text { small insider } \\
& \text { ownership level } \\
- & \text { presence of founders } \\
& \text { on board }\end{array}$ & 71 & Founders' firms & $\begin{array}{ll}\text { - } & \text { strong presence of } \\
& \text { founders on board } \\
\text { - } & \text { concentrated } \\
& \text { ownership with high } \\
& \text { insider ownership level } \\
\text { - } & \text { active presence of } \\
\text { institutional investors } \\
\text { among owners }\end{array}$ \\
\hline 5 & 66 & $\begin{array}{l}\text { Dominance } \\
\text { of insider } \\
\text { ownership }\end{array}$ & $\begin{array}{l}\text { - } \text { the highest insider } \\
\text { ownership level } \\
\text { - } \text { concentrated } \\
\text { ownership } \\
\text { - } 40 \% \text { CEO-duality }\end{array}$ & 127 & $\begin{array}{l}\text { Concentrated } \\
\text { ownership }\end{array}$ & $\begin{array}{l}\text { - } \text { the highest } \\
\text { concentration ratio } \\
\text { - } \text { active presence of both } \\
\text { institutional investors } \\
\text { and insiders among } \\
\text { owners } \\
\text { - } 50 \% \text { CEO-duality }\end{array}$ \\
\hline 6 & 174 & $\begin{array}{l}\text { Classic mature } \\
\text { companies }\end{array}$ & $\begin{array}{ll}\text { - } & \text { institutional } \\
& \text { ownership } \\
\text { - } & \text { high leverage ratio } \\
\text { - } & \text { no CEO-duality }\end{array}$ & 289 & $\begin{array}{l}\text { Classic mature } \\
\text { companies }\end{array}$ & $\begin{array}{l}\text { - } \text { institutional ownership } \\
\text { - } \text { high leverage ratio } \\
\text { - no CEO-duality }\end{array}$ \\
\hline 7 & 54 & $\begin{array}{l}\text { Blue chip firms } \\
\text { with solid } \\
\text { CEO-duality }\end{array}$ & $\begin{array}{ll}\text { - } & \text { institutional } \\
& \text { ownership } \\
\text { - } & \text { high leverage ratio } \\
\text { - } & 100 \% \text { CEO-duality }\end{array}$ & 202 & $\begin{array}{l}\text { Blue chip firms } \\
\text { with solid } \\
\text { CEO-duality }\end{array}$ & $\begin{array}{l}\text { - } \quad \text { institutional ownership } \\
\text { - } \text { high leverage ratio } \\
\text { - } \quad 100 \% \text { CEO-duality }\end{array}$ \\
\hline
\end{tabular}

Table 7. Industry distribution among innovative companies' clusters

\begin{tabular}{|c|c|c|c|c|c|c|c|}
\hline Clusters & 1 & 2 & 3 & 4 & 5 & 6 & 7 \\
\hline $\begin{array}{l}\text { Pharmaceutical products } \\
\text { manufacturers }\end{array}$ & 9 & 41 & 45 & 16 & 34 & 75 & 20 \\
\hline $\begin{array}{l}\text { Air and spacecraft } \\
\text { manufacturers }\end{array}$ & 1 & 0 & 2 & 0 & 1 & 8 & 9 \\
\hline $\begin{array}{l}\text { Computer, electronic and } \\
\text { optical products manufacturers }\end{array}$ & 8 & 9 & 25 & 36 & 31 & 91 & 25 \\
\hline Number of companies & 18 & 50 & 72 & 52 & 66 & 174 & 54 \\
\hline
\end{tabular}

Notes: $\left.{ }^{*}\right)$ Pharmaceutical products manufacturers include companies from the following industries: biological products, pharmaceutical preparations, diagnostic substances.

\section{Industry independency}

To check whether the obtained clusters are related to certain industries, we studied the industrial profiles of the innovative companies in each cluster. The analysis showed that each cluster contains companies from various industries. The industrial profile of the companies within each of the financial architecture patterns is presented in table 7 .
The highest presence of pharmaceutical companies (82\%) is observed in the cluster 2 , whereas generally pharmaceutical firms account for $50 \%$ of the whole sample of innovative firms. Even though the concentration ratio is relatively high, pharmaceutical companies include companies from different industries: 24 biological products, 5 diagnostic substances and 12 pharmaceutical preparations manufacturers. Therefore, the obtained patterns are 
indifferent to the industry factor. To conclude, there is no industry influence on the financial designs of innovative companies, and we do not reject $H 2$. The same result holds true for non-innovative companies. It is also proven by the industrial profiles of the patterns presented in the annex (table A5).

\section{Robustness check}

In addition, we examine the robustness of the results by applying the portioning around medoids (PAM) method to cluster final samples of innovative and non-innovative firms. Our findings show that no significant differences between HCA and PAM clusters were found. The results are presented in the annex. (Tables A6 and Table A7). Even though PAM-based clusters have slightly different number of companies in each cluster in comparison to HCA-based clusters, the general patterns stay the same. Therefore, we may conclude that all the above-mentioned financial architecture patterns are sustainable.

\section{Conclusion and discussion}

This paper examines the core features of financial architecture patterns among US innovative companies in the manufacturing sector, focusing on the possible links between innovation activity and the framework driven by the interrelated corporate structures. Unlike previous studies, we apply the financial architecture concept and clustering approach to account for interrelations between ownership, capital structures and corporate governance mechanisms. The presented evidence indicates that innovative companies follow seven sustainable patterns of financial architecture including patterns with mostly concentrated ownership structure ("owner-manager-controlled", "start-ups", and "dominance of insider ownership"), with dispersed ownership structure («diversified ownership», «dependent board») and active presence of institutional ownership («classic mature companies», «blue chip firms with solid CEO-duality»). We show that large innovative companies prefer to use long-term debt as a source of financing, while small and medium-sized firms mainly rely on short-term debt. At the same time, we observe that clusters with strong insider ownership and blue chip companies demonstrate solid CEO-duality, which highlights the crucial role of the CEO's board power in the financial architecture of innovative companies. Consistent with our expectations, the presented analysis does not reveal strong relations between clusters and industries.

Building on the thorough analysis of the patterns in non-innovative firms, we reveal differences in financial architecture patterns between innovative and non-innovative types of companies. The peculiarities of innovative companies were observed on a cluster-by-cluster basis. In fact, four out of seven financial architecture patterns are unique to innovative firms ("owner-manager-controlled", "start-ups", "founders' firms", and "concentrated ownership") whereas the remaining three patterns demonstrate similarities with non-innovative patterns.
Our findings allow us to identify the crucial differences between innovative and non-innovative firms. First, innovative companies prefer equity to debt financing, and therefore are less leveraged than non-innovative firms, given high costs of debt and financial restrictions implied by creditors for the engagement in risky operations and high losses in case of default. Second, innovative companies have a higher share of activist institutional investors by virtue of active monitoring and long-term investment horizons of shareholder activists. Third, the practice of a CEO serving as a chairman of the board is an important pivot characteristic of innovative firms, which differentiates innovative clusters in relation to each other. Meanwhile, the CEO-duality parameter does not significantly impact the final patterns of financial architectures for non-innovative companies. The obtained results confirm the existence of differences among financial architecture patterns of innovative and non-innovative companies.

Moreover, we argue that the examined financial architecture patterns correspond to different financial-and-market-based performance. In particular, mature companies show the best returns on assets among innovative peers, whereas start-ups and firms with diversified ownership have the highest market-to-book ratios based on investor's expectations.

Our study has certain limitations, including a limited selection criteria for innovative firms and sample size. Therefore, further research will focus on the improvement of the selection criteria of innovative firms and on the inclusion of a life-cycle variable within a 'clustering' analysis (i.e. the observed correlation between company's age, size and financial performance).

\section{References}

1. Bettencourt L.A., Ostrom A.L., Brown S.W., Roundtree R.I. Client co-production in knowledgeintensive business services. California Management Review. 2002;44(4):100-128. DOI: 10.2307/41166145

2. Laursen K., Salter A. Open for innovation: The role of openness in explaining innovation performance among U.K. manufacturing firms. Strategic Management Journal. 2006;27(2):131-150. DOI: 10.1002/smj.507

3. De Jong J.P., Vermeulen P.A. Determinants of product innovation in small firms: A comparison across industries. International Small Business Journal. 2006;24(6):587-609. DOI: $10.1177 / 0266242606069268$

4. Shane S. Cultural influences on national rates of innovation. Journal of Business Venturing. 1993;8(1):59-73. DOI: 10.1016/0883-9026(93)90011S

5. Myers S.C. Financial architecture. European Financial Management. 1999;5(2):133-141. DOI: 10.1111/1468036X.00086 
6. Ivashkovskaya I., Stepanova A. Does strategic corporate performance depend on corporate financial architecture? Empirical study of European, Russian and other emerging market's firms. Journal of Management Governance.2011;15(4):603-616. DOI: 10.1007/s10997-010-9132-7

7. Morck R., A. Shleifer, Vishny R.W. Management ownership and market valuation: An empirical analysis. Journal of Financial Economics. 1988;20(12):293-315.

8. Black B., Kim W. The effect of board structure on firm value: A multiple identification strategies approach using Korean data. Journal of Financial Economics. 2012;104(1):203-226. DOI: 10.1016/j. jineco.2011.08.001

9. Brailsford T.J., Oliver B.R., Pua S.L. On the relation between ownership structure and capital structure. Accounting \& Finance. 2002;42(1):1-26. DOI: 10.1111/1467-629X.00001

10. Minetti R., Murro P., Paiella M. Ownership structure, governance, and innovation. European Economic Review. 2015;80:165-193. DOI: 10.1016/j. euroecorev.2015.09.007

11. Aghion P., Bond S., Klemm A., Marinescu I. Technology and financial structure: Are innovative firms different? Journal of the European Economic Association. 2004;2(2-3): 277-288. DOI: $10.1162 / 154247604323067989$

12. Shapiro D., Tang Y., Wang M., Zhang W. The effects of corporate governance and ownership on the innovation performance of Chinese SMEs. Journal of Chinese Economic and Business Studies. 2015;13(4):311-335. DOI: $10.1080 / 14765284.2015 .1090267$

13. Ivashkovskaya I.V., Stepanova A.N., Kokoreva M.S. Financial architecture of companies. Comparative studies in developed and emerging markets. Moscow: Infra-M Publ.; 2013. 238 p. (In Russ.).

14. Kokoreva M.S., Stepanova A.N. Financial architecture and corporate performance: Evidence from Russia. Korporativnye finansy = Journal of Corporate Finance Research. 2012;6(2):34-44. DOI: 10.17323/j.jcfr.20730438.6.2.2012.34-44

15. Vicente-Lorente J.D. Specificity and opacity as resource-based determinants of capital structure: Evidence for Spanish manufacturing firms. Strategic Management Journal. 2001;22(2):157-177. DOI: 10.1002/1097-0266(200101)22:2<157::AIDSMJ152>3.0.CO;2-2

16. O'brien J.P. The capital structure implications of pursuing a strategy of innovation. Strategic Management Journal. 2003;24(5):415-431. DOI: 10.1002/smj.308
17. Aghion P., Van Reenen J., Zingales L. Innovation and institutional ownership. American economic review. 2013;103(1): 277-304. DOI: $10.1257 /$ aer.103.1.277

18. Eng L., Shackell M. The implications of long-term performance plans and institutional ownership for firms' research and development (R\&D) investments. Journal of Accounting, Auditing and Finance. 20001;16(2):117-139. DOI: $10.1177 / 0148558 X 0101600204$

19. Ortega-Argilés R., Moreno R. Evidence on the role of ownership structure on firms' innovative performance. Investigaciones Regionales-Journal of Regional Research. 2009;(15):231-250.

20. Hill C.W., Snell S.A. External control, corporate strategy, and firm performance in research-intensive industries. Strategic Management Journal. 1988;9(6):577-590. DOI: $10.1002 /$ smj.4250090605

21. Lacetera N. Corporate governance and the governance of innovation: The case of pharmaceutical industry. Journal of Management and Governance. 2001;5(1):29-59. DOI: 10.1023/A:101790711

22. Chen Y.-S., Lin M.-J.J., Chang C.-H. The positive effects of relationship learning and absorptive capacity on innovation performance and competitive advantage in industrial markets. Industrial Marketing Management. 2009;38(2):152-158. DOI: 10.1016/j. indmarman.2008.12.003

23. Chang X., Hilary G., Kang J.-K., Zhang W. Does accounting conservatism impede corporate innovation? SSRN Electronic Journal. 2013;(Feb). DOI: $10.2139 /$ ssrn.2189938

24. Graham J.R., Harvey C.R., Rajgopal S. Value destruction and financial reporting decisions. Financial Analysts Journal. 2006;62(6):27-39. DOI: 10.2469/faj.v62.n6.4351

25. Harrison J.R., Torres D.L., Kukalis S. The changing of the guard: Turnover and structural change in the top-management positions. Administrative Science Quarterly. 1988;33(2):211-232. DOI: $10.2307 / 2393056$

26. Michaelas N., Chittenden F., Poutziouris P. Financial policy and capital structure choice in UK SMEs: Empirical evidence from company panel data. Small Business Economics.1999;12(2):113-130. DOI: 10.1023/A:1008010724051

27. Oslo manual: Guidelines for collecting and interpreting innovation data. $3^{\text {rd }}$ ed. Paris: OECD; 2005. 166 p. URL: https://www.oecd-ilibrary.org/ docserver/9789264013100-en.pdf? expires $=15429698$ 34\&id $=\mathrm{id} \&$ accname $=$ guest $\&$ checksum $=$ EBD05750E DCE1F756ABC829303A717FF 
28. Kirner E., Kinkel S., Jaeger A. Innovation paths and the innovation performance of low-technology firms - An empirical analysis of German industry. Research Policy. 2009;38(3):447-458. DOI: 10.1016/j. respol.2008.10.011

29. Kleinknecht A.H. Measuring product and service innovation: An assessment of alternative indicators. Rotterdam: RIBES - Rotterdam Institute for Business Economic Studies; 1999.

30. Earle J.S., Csaba K., Álmos T. Ownership concentration and corporate performance on the Budapest stock exchange: Do too many cooks spoil the goulash? Corporate Governance: An International Review. 2005;13(2):254-264. DOI: $10.1111 / \mathrm{j} .1467-8683.2005 .00420 . \mathrm{x}$

31. Hovey M., Li L., Naughton T. The relationship between valuation and ownership of listed firms in China. Corporate Governance: An International Review. 2003;11(2):112-122.

DOI: $10.1111 / 1467-8683.00012$

32. Lauterbach B., Vaninsky A. Ownership structure and firm performance: Evidence from Israel. Journal of Management and Governance. 1999;3(2):189-201. DOI: 10.1023/A:1009990008724

33. Hoskisson R.E., Hitt M.A., Johnson R.A., Grossman W. Conflicting voices: The effects of institutional ownership heterogeneity and internal governance on corporate innovation strategies. The Academy of Management journal. 2002;45(4):697-716. DOI: $10.2307 / 3069305$ 
Table A1. The descriptive statistics of innovative companies

\begin{tabular}{|c|c|c|c|c|c|c|}
\hline & Min & 1st Qu & Median & Mean & 3rd Qu & $\operatorname{Max}$ \\
\hline \multicolumn{7}{|l|}{ General } \\
\hline Age & 1.00 & 16.25 & 26.00 & 32.93 & 36.00 & 300.00 \\
\hline Revenue, \$m & 0.13 & 14.16 & 79.97 & $2,890.56$ & 751.99 & $234,988.00$ \\
\hline Assets, $\$ \mathrm{~m}$ & 0.45 & 48.52 & 200.22 & $4,630.44$ & $1,127.91$ & $293,284.00$ \\
\hline ia_ta, \% & 0.00 & 0.00 & 7.56 & 15.76 & 28.44 & 92.17 \\
\hline rd_sales, \% & 0.00 & 0.00 & 6.69 & 357.20 & 20.15 & $49,018.93$ \\
\hline Gr_sales, $\%$ & $(75.19)$ & $(3.11)$ & 3.73 & 22.34 & 18.59 & $1,245.63$ \\
\hline ROA, \% & $(127.42)$ & $(18.71)$ & $(1.13)$ & $(9.35)$ & 4.90 & 50.96 \\
\hline tobinq & 0.11 & 0.91 & 1.57 & 2.22 & 2.91 & 13.37 \\
\hline \multicolumn{7}{|c|}{ Capital structure } \\
\hline LTDebt_cap, \% & 0.00 & 0.00 & 2.12 & 20.51 & 31.81 & 187.75 \\
\hline Debt_cap, $\%$ & 0.00 & 0.00 & 14.16 & 26.92 & 42.16 & 248.42 \\
\hline \multicolumn{7}{|c|}{ Ownership structure } \\
\hline Top 1, \% & 1.78 & 8.58 & 11.96 & 16.28 & 18.83 & 75.74 \\
\hline Top5, \% & 1.89 & 26.53 & 35.25 & 37.27 & 45.83 & 100.00 \\
\hline Institutions, \% & 0.00 & 15.78 & 34.04 & 36.82 & 57.18 & 97.43 \\
\hline Active_inst, \% & 0.00 & 11.09 & 26.01 & 27.26 & 40.43 & 84.58 \\
\hline Passive_inst, \% & 0.00 & 1.90 & 8.14 & 9.65 & 16.37 & 66.88 \\
\hline Insiders, $\%$ & 0.00 & 0.54 & 3.01 & 9.66 & 11.83 & 77.36 \\
\hline VCPE, \% & 0.00 & 0.00 & 0.00 & 4.55 & 0.36 & 86.74 \\
\hline \multicolumn{7}{|c|}{ Corporate governance } \\
\hline Duality & 0.00 & 0.00 & 0.00 & 0.35 & 1.00 & 1.00 \\
\hline Founder, \% & 0.00 & 0.00 & 0.00 & 3.65 & 5.20 & 33.33 \\
\hline $\mathrm{CFO}, \%$ & 0.00 & 0.00 & 0.00 & 1.44 & 0.00 & 33.33 \\
\hline Scientists, $\%$ & 0.00 & 0.00 & 0.00 & 10.20 & 11.11 & 80.00 \\
\hline Board_size & 2.00 & 7.00 & 9.00 & 9.28 & 11.00 & 20.00 \\
\hline
\end{tabular}

Table A2. The descriptive statistics of non-innovative companies

\begin{tabular}{|c|c|c|c|c|c|c|}
\hline & Min & 1st Qu & Median & Mean & 3rd Qu & $\operatorname{Max}$ \\
\hline \multicolumn{7}{|l|}{ General } \\
\hline Age & 1.00 & 23.00 & 46.00 & 59.32 & 90.00 & 649.00 \\
\hline Revenue, \$m & 0.12 & 79.28 & 709.87 & $4,623.26$ & $2,887.07$ & $236,810.00$ \\
\hline Assets, \$m & 0.10 & 85.70 & 656.70 & $6,029.60$ & $3,152.50$ & $336,758.00$ \\
\hline ia_ta, \% & 0.00 & 2.02 & 12.54 & 19.57 & 31.50 & 95.73 \\
\hline rd_sales, \% & 0.00 & 0.00 & 0.00 & 25.28 & 4.64 & $4,055.93$ \\
\hline Gr_sales, \% & $(78.26)$ & $(3.09)$ & 2.55 & 8.24 & 9.38 & $1,280.05$ \\
\hline
\end{tabular}




\begin{tabular}{|c|c|c|c|c|c|c|}
\hline & Min & 1st $\mathbf{Q u}$ & Median & Mean & 3rd Qu & $\operatorname{Max}$ \\
\hline $\mathrm{ROA}, \%$ & $(147.92)$ & 0.53 & 4.87 & 0.36 & 7.98 & 44.63 \\
\hline tobinq & 0.07 & 0.72 & 1.13 & 1.82 & 1.93 & 102.44 \\
\hline \multicolumn{7}{|c|}{ Capital structure } \\
\hline LTDebt_cap, \% & 0.00 & 0.01 & 21.18 & 26.96 & 42.53 & 193.81 \\
\hline Debt_cap, \% & 0.00 & 5.62 & 30.29 & 37.72 & 50.96 & $1,690.23$ \\
\hline \multicolumn{7}{|c|}{ Ownership structure } \\
\hline Top1, \% & 0.99 & 8.08 & 10.93 & 16.94 & 18.50 & 92.60 \\
\hline Top5, \% & 0.99 & 27.26 & 33.68 & 37.84 & 44.25 & 100.00 \\
\hline Institutions, \% & 0.00 & 18.88 & 48.16 & 42.07 & 60.73 & 100.00 \\
\hline Active_inst, \% & 0.00 & 11.00 & 28.48 & 28.04 & 43.95 & 99.72 \\
\hline Passive_inst, \% & 0.00 & 5.21 & 14.18 & 14.07 & 19.27 & 75.96 \\
\hline Insiders, \% & 0.00 & 0.39 & 2.41 & 10.38 & 13.51 & 88.01 \\
\hline VCPE, \% & 0.00 & 0.00 & 0.00 & 1.70 & 0.00 & 74.15 \\
\hline \multicolumn{7}{|c|}{ Corporate governance } \\
\hline Duality & 0.00 & 0.00 & 0.00 & 0.41 & 1.00 & 1.00 \\
\hline Founder, \% & 0.00 & 0.00 & 0.00 & 1.73 & 0.00 & 50.00 \\
\hline $\mathrm{CFO}, \%$ & 0.00 & 0.00 & 0.00 & 1.84 & 0.00 & 50.00 \\
\hline Scientists, \% & 0.00 & 0.00 & 0.00 & 1.76 & 0.00 & 77.78 \\
\hline Board_size & 1.00 & 7.00 & 9.00 & 8.84 & 11.00 & 20.00 \\
\hline
\end{tabular}

Table A3. The descriptive statistics of innovative companies' clusters (mean by HCA-method)

\begin{tabular}{|c|c|c|c|c|c|c|c|}
\hline Variables - mean & 1 & 2 & 3 & 4 & 5 & 6 & 7 \\
\hline Age & 33.1 & 21.8 & 31.5 & 28.6 & 30.3 & 34.0 & 49.1 \\
\hline Revenue, $\$ \mathrm{~m}$ & 42.2 & 430.1 & $2,037.2$ & $1,869.1$ & 275.8 & $3,913.9$ & $8,137.9$ \\
\hline Assets, \$m & 68.5 & 518.2 & $3,776.5$ & $1,893.5$ & 600.5 & $5,647.5$ & $15,381.2$ \\
\hline $\mathrm{ROA}, \%$ & $(16.0)$ & $(23.4)$ & $(17.1)$ & $(10.5)$ & $(12.3)$ & $(3.9)$ & 3.4 \\
\hline Gr_sales, \% & 0.8 & 48.4 & 31.1 & 21.3 & 19.1 & 18.5 & 11.0 \\
\hline ia_ta, \% & 13.7 & 12.3 & 10.9 & 11.9 & 14.0 & 18.0 & 24.7 \\
\hline tobinq & 1.6 & 2.8 & 2.4 & 1.8 & 2.0 & 2.2 & 2.5 \\
\hline rd_sales, \% & 1.9 & $1,566.7$ & 443.7 & 212.4 & 642.0 & 53.3 & 10.8 \\
\hline LTDebt_cap, \% & 12.8 & 18.4 & 19.0 & 8.4 & 17.1 & 24.6 & 29.7 \\
\hline Debt_cap, \% & 31.9 & 25.1 & 24.2 & 14.3 & 31.1 & 28.2 & 33.5 \\
\hline Top1, \% & 29.5 & 24.6 & 7.6 & 12.2 & 31.4 & 12.8 & 12.5 \\
\hline Top5, \% & 47.5 & 53.6 & 18.9 & 26.3 & 52.9 & 36.1 & 38.4 \\
\hline Institutions, \% & 5.6 & 22.4 & 17.6 & 22.5 & 16.6 & 55.7 & 64.2 \\
\hline Insiders, \% & 32.3 & 4.3 & 5.7 & 10.1 & 34.5 & 3.4 & 3.8 \\
\hline VCPE, \% & 0.0 & 34.8 & 1.4 & 1.8 & 1.2 & 1.1 & 0.2 \\
\hline
\end{tabular}




\begin{tabular}{|c|c|c|c|c|c|c|c|}
\hline Variables - mean & 1 & 2 & 3 & 4 & 5 & 6 & 7 \\
\hline Active_institutions, \% & 3.4 & 19.0 & 12.5 & 17.5 & 13.2 & 40.1 & 47.8 \\
\hline Passive_institutions, \% & 2.2 & 3.4 & 5.2 & 5.1 & 3.4 & 15.8 & 16.4 \\
\hline Duality & 1.0 & 0.2 & 0.1 & 1.0 & 0.4 & 0.0 & 1.0 \\
\hline Founder, \% & 6.7 & 5.7 & 1.2 & 8.0 & 2.5 & 3.2 & 2.8 \\
\hline $\mathrm{CFO}, \%$ & 22.7 & 0.3 & 1.4 & 0.7 & 0.1 & 0.8 & 0.0 \\
\hline Scientists, \% & 0.7 & 23.7 & 20.0 & 3.5 & 13.4 & 6.2 & 3.4 \\
\hline Board_size & 5.0 & 11.1 & 10.2 & 7.6 & 8.4 & 9.5 & 10.0 \\
\hline \# of companies & 18 & 50 & 72 & 52 & 66 & 174 & 54 \\
\hline
\end{tabular}

Table A4. The descriptive statistics of non-innovative companies' clusters (mean by HCA-method)

\begin{tabular}{|c|c|c|c|c|c|c|c|}
\hline Variables - mean & 1 & 2 & 3 & 4 & 5 & 6 & 7 \\
\hline Age & 34.2 & 28.1 & 40.7 & 31.1 & 56.9 & 64.6 & 80.2 \\
\hline Revenue, \$m & 12.8 & 701.6 & $1,158.8$ & $1,678.6$ & $2,088.3$ & $4,509.3$ & $10,374.7$ \\
\hline Assets, \$m & 11.0 & 765.5 & $1,707.3$ & $2,588.3$ & $3,409.7$ & $5,576.1$ & $13,304.0$ \\
\hline ROA, \% & $(15.5)$ & $(5.2)$ & $(13.6)$ & $(2.0)$ & $(0.2)$ & 4.4 & 6.5 \\
\hline Gr_sales, \% & 45.5 & 56.2 & 9.1 & 15.6 & 6.3 & 2.7 & 3.8 \\
\hline ia_ta, \% & 11.5 & 20.2 & 9.8 & 13.4 & 13.5 & 25.0 & 24.5 \\
\hline tobinq & 2.5 & 1.7 & 2.5 & 2.3 & 1.6 & 1.4 & 1.5 \\
\hline rd_sales, $\%$ & 10.5 & 89.8 & 119.0 & 54.2 & 5.4 & 4.6 & 2.0 \\
\hline LTDebt_cap, \% & 38.7 & 30.8 & 8.9 & 15.9 & 24.3 & 34.2 & 33.3 \\
\hline Debt_cap, \% & 74.4 & 45.7 & 18.3 & 46.0 & 47.6 & 38.2 & 37.5 \\
\hline Top1, \% & 24.7 & 38.6 & 10.0 & 18.7 & 41.1 & 10.7 & 10.5 \\
\hline Top5, \% & 40.8 & 59.7 & 24.1 & 40.8 & 63.5 & 32.9 & 32.6 \\
\hline Institutions, $\%$ & 4.0 & 19.2 & 18.5 & 33.7 & 21.7 & 56.3 & 58.2 \\
\hline Insiders, $\%$ & 35.2 & 3.6 & 8.8 & 21.9 & 25.1 & 4.3 & 3.5 \\
\hline VCPE, \% & 0.6 & 43.1 & 2.0 & 1.0 & 0.7 & 0.5 & 0.2 \\
\hline Active_institutions, \% & 3.1 & 13.0 & 12.1 & 18.2 & 13.1 & 38.7 & 39.5 \\
\hline Passive_institutions, \% & 0.8 & 6.3 & 6.5 & 15.5 & 8.6 & 17.7 & 18.8 \\
\hline Duality & 0.5 & 0.5 & 0.3 & 0.5 & 0.5 & 0.0 & 1.0 \\
\hline Founder, \% & 1.7 & 0.0 & 0.7 & 17.7 & 0.2 & 0.2 & 0.0 \\
\hline $\mathrm{CFO}, \%$ & 28.1 & 2.1 & 0.3 & 2.1 & 1.9 & 0.5 & 0.8 \\
\hline Scientists, \% & 3.2 & 8.6 & 8.5 & 0.9 & 1.3 & 0.0 & 0.3 \\
\hline Board_size & 4.0 & 9.1 & 8.6 & 7.3 & 8.2 & 9.4 & 9.9 \\
\hline \# of companies & 30 & 20 & 110 & 71 & 127 & 289 & 202 \\
\hline
\end{tabular}


Table A5. Industry distribution among non-innovative companies' clusters

\begin{tabular}{|c|c|c|c|c|c|c|c|c|}
\hline Industry & 1 & 2 & 3 & 4 & 5 & 6 & 7 & Total \\
\hline Healthcare equipment & 4 & 5 & 20 & 13 & 8 & 19 & 13 & 82 \\
\hline Industrial machinery & 1 & 0 & 8 & 4 & 8 & 32 & 21 & 74 \\
\hline Specialty chemicals & 0 & 0 & 4 & 1 & 6 & 7 & 19 & 37 \\
\hline Packaged foods and meats & 0 & 1 & 1 & 4 & 12 & 12 & 6 & 36 \\
\hline Electrical components and equipment & 2 & 2 & 9 & 0 & 4 & 7 & 13 & 37 \\
\hline Auto parts and equipment & 1 & 0 & 3 & 4 & 6 & 15 & 5 & 34 \\
\hline Electronic equipment and instruments & 2 & 1 & 6 & 2 & 5 & 13 & 4 & 33 \\
\hline Building products & 1 & 1 & 3 & 0 & 3 & 13 & 8 & 29 \\
\hline Oil and gas refining and marketing & 1 & 1 & 6 & 2 & 3 & 6 & 6 & 25 \\
\hline Apparel. accessories \& luxury goods & 0 & 1 & 3 & 3 & 6 & 4 & 8 & 25 \\
\hline Semiconductor equipment & 1 & 0 & 1 & 5 & 0 & 14 & 2 & 23 \\
\hline Construction machinery \& trucks & 0 & 0 & 1 & 0 & 2 & 11 & 9 & 23 \\
\hline Healthcare Supplies & 0 & 1 & 3 & 1 & 2 & 10 & 3 & 20 \\
\hline Aerospace and Defense & 1 & 0 & 1 & 0 & 5 & 5 & 6 & 18 \\
\hline Leisure products & 2 & 1 & 1 & 1 & 3 & 6 & 4 & 18 \\
\hline Commodity Chemicals & 2 & 0 & 1 & 0 & 6 & 5 & 2 & 16 \\
\hline Steel & 0 & 0 & 2 & 1 & 1 & 7 & 5 & 16 \\
\hline Soft Drinks & 2 & 0 & 2 & 2 & 3 & 3 & 2 & 14 \\
\hline Home furnishings & 1 & 0 & 1 & 0 & 2 & 2 & 6 & 12 \\
\hline Other & 9 & 6 & 34 & 28 & 42 & 98 & 60 & 277 \\
\hline Total & 30 & 20 & 110 & 71 & 127 & 289 & 202 & 849 \\
\hline
\end{tabular}

Table A6. The descriptive statistics of innovative companies' clusters (median by PAM-method)

\begin{tabular}{|c|c|c|c|c|c|c|c|}
\hline Variables - median & 1 & 2 & 3 & 4 & 5 & 6 & 7 \\
\hline Age & 33.0 & 11.5 & 19.0 & 24.0 & 31.0 & 31.5 & 29.0 \\
\hline Revenue, \$m & 10.5 & 13.2 & 11.8 & 36.2 & 55.0 & 589.1 & 815.5 \\
\hline Assets, \$m & 8.1 & 105.2 & 101.0 & 57.1 & 77.2 & 914.5 & $1,192.6$ \\
\hline $\mathrm{ROA}, \%$ & $(5.1)$ & $(24.2)$ & $(20.9)$ & $(3.5)$ & $(0.6)$ & 3.6 & 4.5 \\
\hline Gr_sales, \% & $(0.3)$ & 10.5 & 2.2 & 2.0 & 3.8 & 5.3 & 6.6 \\
\hline ia_ta, \% & 0.6 & 0.8 & 0.0 & 2.9 & 5.6 & 16.2 & 15.9 \\
\hline tobinq & 1.1 & 2.3 & 3.1 & 1.6 & 0.9 & 1.4 & 1.5 \\
\hline rd_sales, \% & 0.0 & 6.6 & 7.9 & 5.6 & 7.0 & 9.4 & 7.0 \\
\hline LTDebt_cap, \% & 0.0 & 1.6 & 0.0 & 0.0 & 0.0 & 24.6 & 23.4 \\
\hline Debt_cap, \% & 3.8 & 10.1 & 0.0 & 4.1 & 3.0 & 28.8 & 28.8 \\
\hline Top 1, \% & 22.6 & 19.1 & 10.4 & 9.3 & 28.5 & 11.0 & 10.2 \\
\hline Top5, \% & 47.5 & 54.4 & 21.1 & 25.2 & 54.5 & 34.6 & 33.0 \\
\hline
\end{tabular}




\begin{tabular}{|c|c|c|c|c|c|c|c|}
\hline Variables - median & 1 & 2 & 3 & 4 & 5 & 6 & 7 \\
\hline Institutions, \% & 5.0 & 21.7 & 19.5 & 20.2 & 13.1 & 59.7 & 55.6 \\
\hline Insiders, \% & 31.1 & 1.9 & 2.8 & 6.8 & 36.2 & 0.8 & 0.9 \\
\hline VCPE, \% & 0.0 & 36.0 & 0.0 & 0.0 & 0.0 & 0.0 & 0.0 \\
\hline Active_institutions, \% & 2.8 & 17.5 & 10.9 & 15.7 & 11.5 & 41.7 & 38.2 \\
\hline Passive_institutions, \% & 0.0 & 2.4 & 8.3 & 4.4 & 0.0 & 17.6 & 16.4 \\
\hline Duality & 1.0 & 0.0 & 0.0 & 1.0 & 0.0 & 0.0 & 1.0 \\
\hline Founder, \% & 0.0 & 5.9 & 0.0 & 0.0 & 0.0 & 0.0 & 0.0 \\
\hline $\mathrm{CFO}, \%$ & 20.0 & 0.0 & 0.0 & 0.0 & 0.0 & 0.0 & 0.0 \\
\hline Scientists, \% & 0.0 & 25.0 & 0.0 & 0.0 & 0.0 & 0.0 & 0.0 \\
\hline Board_size & 5.0 & 11.0 & 13.0 & 7.0 & 7.0 & 9.0 & 9.0 \\
\hline \# of companies & 23 & 42 & 69 & 54 & 68 & 157 & 73 \\
\hline
\end{tabular}

Table A7. The descriptive statistics of non-innovative companies' clusters (median by PAM-method)

\begin{tabular}{|c|c|c|c|c|c|c|c|}
\hline Variables - median & 1 & 2 & 3 & 4 & 5 & 6 & 7 \\
\hline Age & 29.0 & 17.0 & 29.0 & 29.5 & 40.0 & 54.0 & 72.0 \\
\hline Revenue, \$m & 9.5 & 122.9 & 44.7 & 265.2 & 121.7 & $1,228.1$ & $2,414.7$ \\
\hline Assets, \$m & 11.4 & 136.0 & 63.3 & 267.9 & 126.4 & $1,428.3$ & $2,370.7$ \\
\hline $\mathrm{ROA}, \%$ & $(0.6)$ & 0.5 & $(2.3)$ & 3.5 & 3.6 & 5.1 & 6.5 \\
\hline Gr_sales, \% & 4.0 & 14.8 & 2.2 & 6.8 & 2.6 & 1.6 & 2.5 \\
\hline ia_ta, $\%$ & 2.3 & 3.8 & 5.1 & 5.4 & 5.4 & 20.8 & 19.3 \\
\hline tobinq & 1.3 & 1.4 & 1.2 & 1.7 & 1.0 & 1.1 & 1.2 \\
\hline rd_sales, \% & 0.0 & 1.1 & 3.4 & 0.5 & 0.0 & 0.0 & 0.0 \\
\hline LTDebt_cap, \% & 4.4 & 21.7 & 2.2 & 4.8 & 12.7 & 32.3 & 33.5 \\
\hline Debt_cap, \% & 10.6 & 29.2 & 12.4 & 11.4 & 19.4 & 36.7 & 37.3 \\
\hline Top1, \% & 24.6 & 29.7 & 7.8 & 12.9 & 31.8 & 9.6 & 9.2 \\
\hline Top5, \% & 47.1 & 58.3 & 20.3 & 37.4 & 58.9 & 32.3 & 32.2 \\
\hline Institutions, \% & 0.3 & 18.2 & 13.2 & 38.4 & 15.8 & 58.3 & 57.1 \\
\hline Insiders, \% & 32.9 & 2.1 & 5.2 & 18.1 & 25.8 & 1.0 & 1.1 \\
\hline VCPE, \% & 0.0 & 39.0 & 0.0 & 0.0 & 0.0 & 0.0 & 0.0 \\
\hline Active_institutions, \% & 0.0 & 13.9 & 5.2 & 15.3 & 7.5 & 40.4 & 40.8 \\
\hline Passive_institutions, \% & 0.0 & 3.8 & 4.1 & 12.8 & 3.8 & 18.1 & 17.9 \\
\hline Duality & 1.0 & 0.0 & 0.0 & 1.0 & 0.0 & 0.0 & 1.0 \\
\hline Founder, \% & 0.0 & 0.0 & 0.0 & 16.7 & 0.0 & 0.0 & 0.0 \\
\hline $\mathrm{CFO}, \%$ & 20.0 & 0.0 & 0.0 & 0.0 & 0.0 & 0.0 & 0.0 \\
\hline Scientists, \% & 0.0 & 0.0 & 0.0 & 0.0 & 0.0 & 0.0 & 0.0 \\
\hline Board_size & 5.0 & 10.0 & 7.0 & 7.0 & 7.0 & 9.0 & 9.0 \\
\hline \# of companies & 45 & 19 & 104 & 58 & 126 & 289 & 208 \\
\hline
\end{tabular}


Figure A1. The dissimilarity matrices of innovative companies

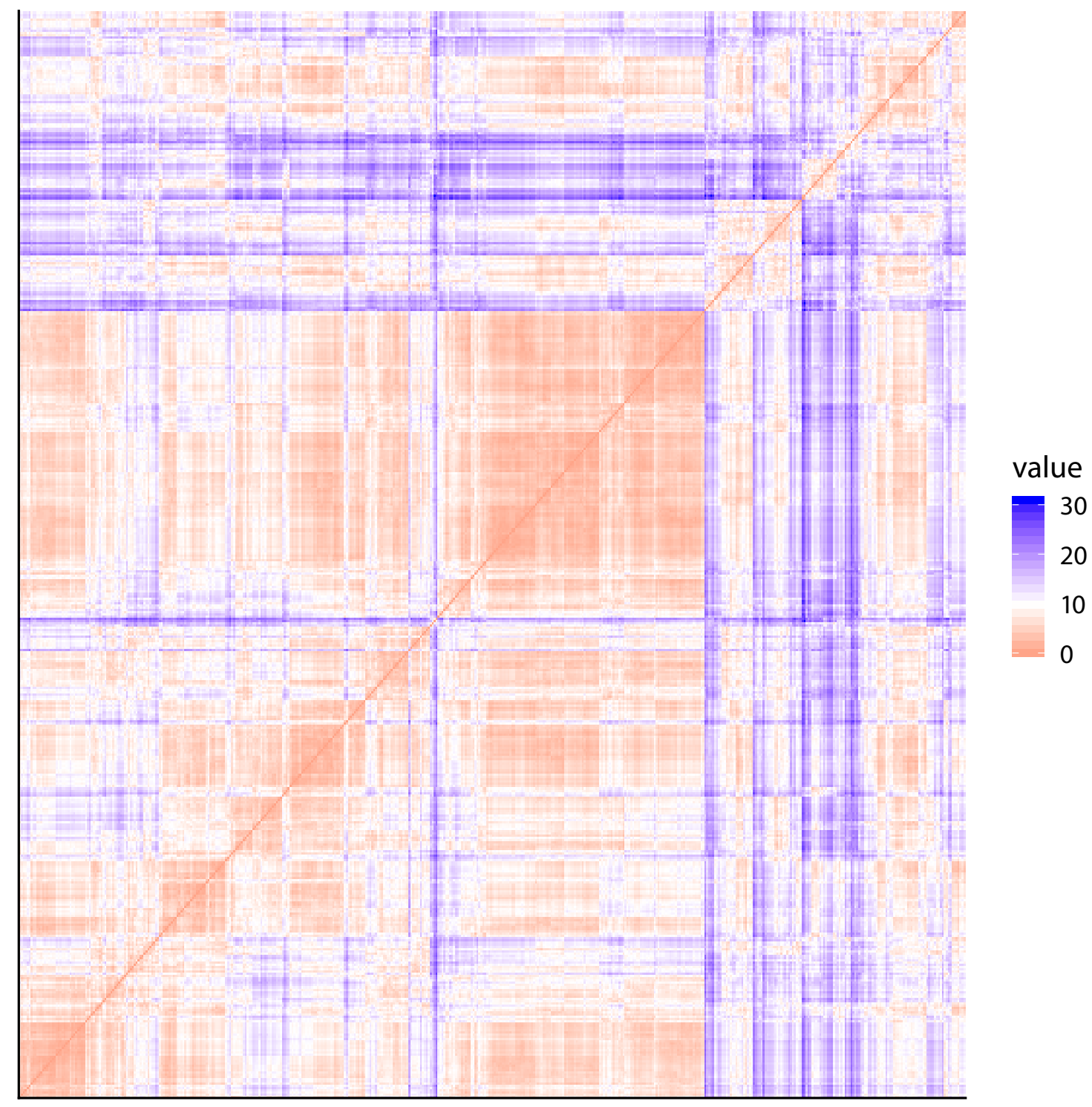

The color level is proportional to the value of the dissimilarity between observations, which assumes a red color if and blue if. Objects belonging to the same cluster are displayed in consecutive order. 
Figure A2. The dissimilarity matrices of non-innovative companies

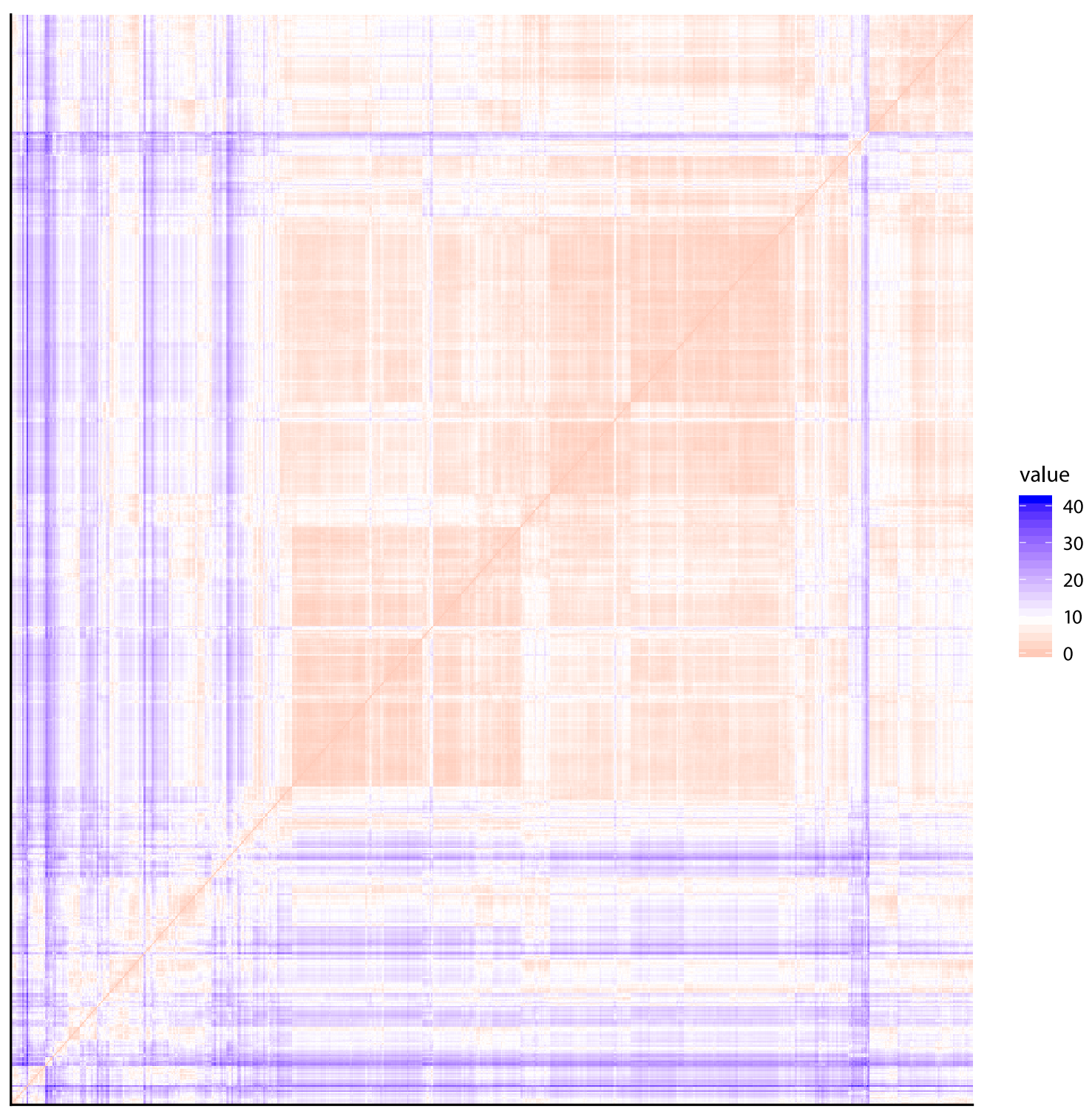

The color level is proportional to the value of the dissimilarity between observations, which assumes a red color if and blue if. Objects belonging to the same cluster are displayed in the consecutive order. 
Figure A3. Graphical and statistical methods for identification of optimal number of clusters

\section{Innovative companies}
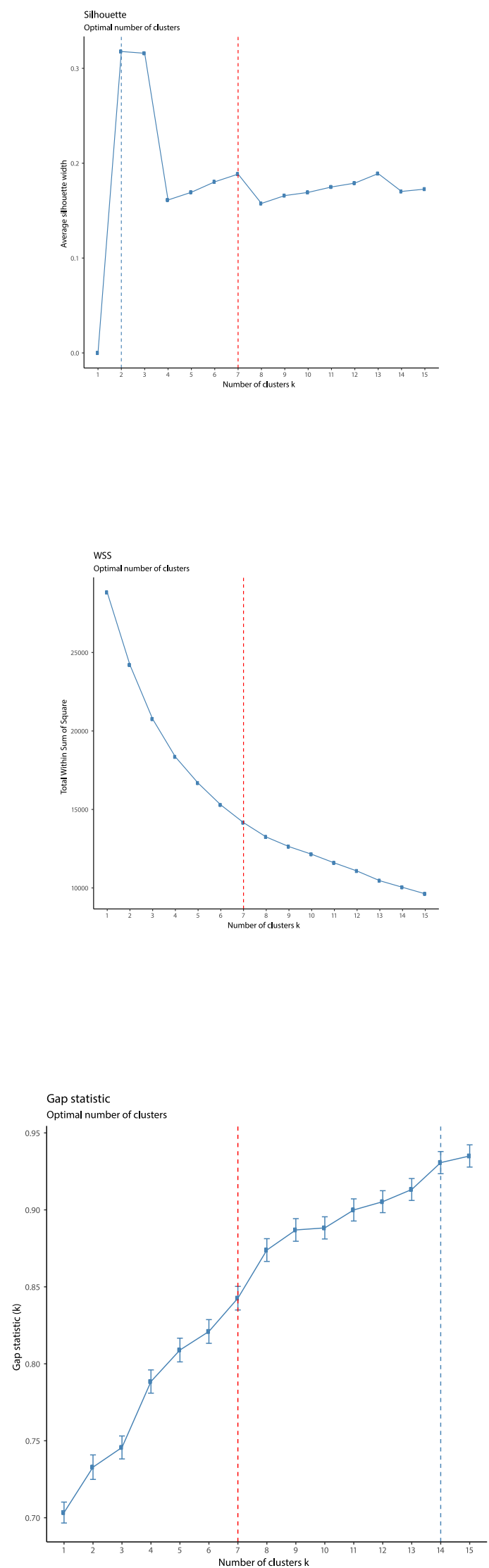

\section{Non-innovative companies}
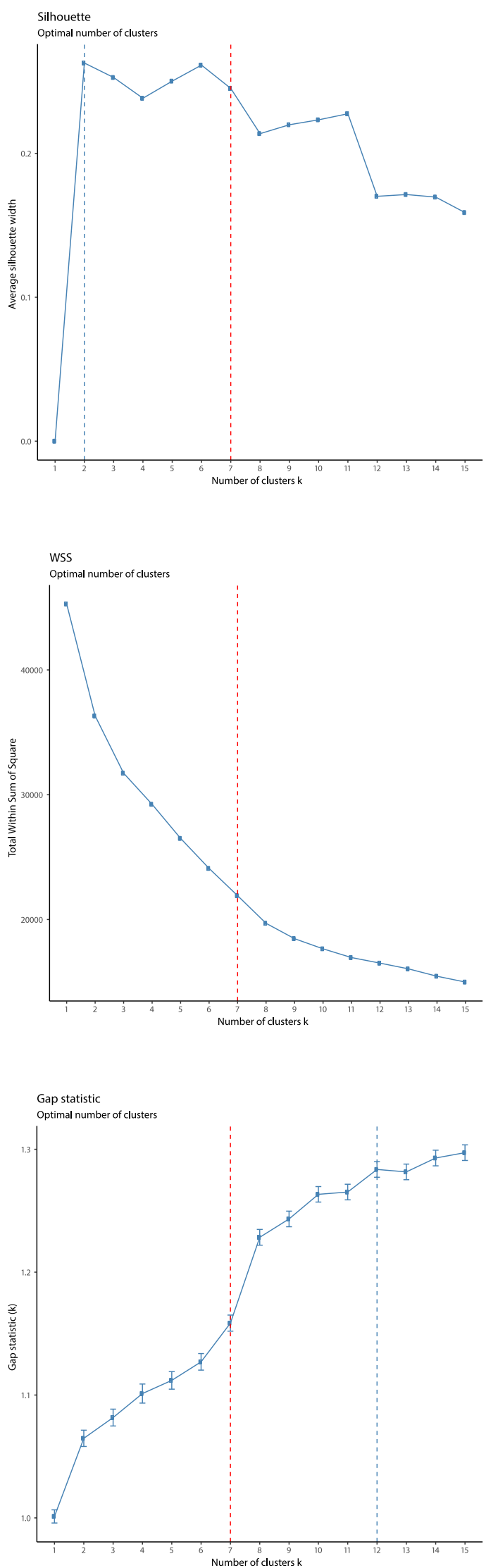